This item was submitted to Loughborough's Research Repository by the author.

Items in Figshare are protected by copyright, with all rights reserved, unless otherwise indicated.

\title{
Postcapitalist precarious work and those in the 'drivers' seat: Exploring the motivations and lived experiences of Uber drivers in Canada
}

PLEASE CITE THE PUBLISHED VERSION

https://doi.org/10.1177/1350508418757332

\section{PUBLISHER}

(C) The Authors. Published by SAGE Publications

\section{VERSION}

AM (Accepted Manuscript)

\section{PUBLISHER STATEMENT}

This work is made available according to the conditions of the Creative Commons Attribution-NonCommercialNoDerivatives 4.0 International (CC BY-NC-ND 4.0) licence. Full details of this licence are available at: https://creativecommons.org/licenses/by-nc-nd/4.0/

\section{LICENCE}

CC BY-NC-ND 4.0

\section{REPOSITORY RECORD}

Peticca-Harris, Amanda, Nadia deGama, and M.N. Ravishankar. 2018. "Postcapitalist Precarious Work and Those in the 'drivers' Seat: Exploring the Motivations and Lived Experiences of Uber Drivers in Canada". Loughborough University. https://hdl.handle.net/2134/27889. 


\title{
Postcapitalist precarious work and those in the 'drivers'" seat: Exploring the motivations and lived experiences of Uber Drivers in Canada
}

\begin{abstract}
In this inductive, qualitative study, we observe how Uber, a company often hailed as being the poster-child of the sharing economy facilitated through a digital platform may also at times represent and reinforce postcapitalist hyper-exploitation. Drawing on the motivations and lived experiences of 31 Uber drivers in Toronto, Canada, we provide insights into three groups of Uber drivers: (1) those that are driving part-time to earn extra money in conjunction with studying or doing other jobs; (2) those that are unemployed and for whom driving for Uber is the only source of income; (3) professional drivers, who are trying to keep pace with the durable digital landscape and competitive marketplace. We emphasize the ways in which each driver group simultaneously acknowledges and rejects their own precarious employment by distancing techniques such as minimizing the risks and accentuating the advantages of the driver role. We relate these findings to a broader discussion about how driving for Uber fuels the traditional capitalist narrative that working hard and having a dream will lead to advancement, security and success. We conclude by discussing other alternative economies within the sharing economy.
\end{abstract}

Keywords: lived experiences, sharing economy, Uber, postcapitalism, digital platforms.

\section{Introduction}

In recent years, several businesses have emerged and proliferated under the umbrella of the socalled sharing economy. The businesses that one might readily associate with the sharing economy span diverse sectors and industries and offer a wide variety of goods and services including accommodation (e.g. AirBnB), transportation (e.g. Zipcar, Lyft, Hailo, and Uber), finance (e.g. Kickstarter), recycling (e.g. Freecyle) and ways to organize and prioritize tasks (e.g. Taskrabbit). Although varied, what these digital ecologies have in common is that this new and seemingly alternative way of conducting business provides a social, economic and technological platform for the working class to share and capitalize on their own skills and resources in their local markets (Belk, 2014; Chen, 2015). The new digital economy, also referred by the 
neologism, the platform economy ${ }^{1}$ is made possible by new kinds of horizontal, networked exchanges and interactions between users through online communities (e.g. Choudary, 2015; Kenny \& Zysman, 2016; Langley \& Leyshon, 2017; Parker et al., 2016). Platforms operate as non-human mediators of market exchanges. The platform economy is structured around “temporary access, non-ownership models of utilizing consumer goods and services [and often rely] on the Internet, and especially Web 2.0...” (Belk, 2014, p. 1595). Often depicted as diverse and re-distributive, the platform economy has characteristics of being flat and democratically available to everyone (Gillespie, 2010). Businesses operating within this digital landscape are distinctive because of ease of sign-up and registration, which makes it possible for anyone to become a supplier and offer a range of products and services with a few quick clicks. Further, platforms act as multi-sided markets and coordinate networked connectivity between customers, individuals and multinational corporations (van Dijck, 2013; Langley \& Leyshon, 2017). In doing so, platform-based business models re-image and reconfigure the role of consumers, producers and ownership. For example, in the coming together of code and commerce, individuals rent out their personal goods and services and these businesses earn a percentage of every peer-to-peer transaction. Consequently, platforms act as a socio-technical intermediary that both requires and produces a different relationship between the worker and the work, their experiences and subjectivities.

In this exploratory study, we examine the lived experiences of 31 Uber drivers in Toronto, Canada who act as platform micro-entrepreneurs and put their personal resources (cars and time) to use for the purpose of earning an income (Arthur, 2014). Through our inductive analysis, we address two research questions. Firstly, what motivates drivers to sacrifice their

\footnotetext{
${ }^{1}$ The coinage can be traced back to the German blogger, Sascha Lobo and her critique of the sharing economy. See: http://www.spiegel.de/netzwelt/netzpolitik/sascha-lobo-sharing-economy-wie-bei-uber-istplattform-kapitalismus-a989584.html
} 
personal time and resources for Uber? And secondly, what are their lived experiences driving for Uber? This article contributes to the existing literature in three ways: first, we examine work experiences associated with the sharing economy that are facilitated by digital platforms. This provides insights into the egression and expansion of the digital economy. Second, we relate the new digital economy to postcapitalism and examine the ways in which platforms are contributing to worker's precariousness and the degradation of work. We illustrate how Uber harnesses the needs and insecurities and not just the passions of the 'productive public' (Arvidsson \& Peitersen, 2013) as drivers simultaneously acknowledge and reject their precariousness with an array of positive and anxiety-inducing experiences We consider the ways in which Uber as an example of a sharing economy platform binds various forms of individual precariousness and economic insecurity to their benefit with little critique or resistance from workers. The third contribution of this study is that we highlight how notwithstanding Uber's efforts to project itself as a good sharing economy alternative to the mainstream, drivers may not necessarily consider Uber to be a 'good' organization. Rather, given their precariousness it is simply deemed as something better than what else is on offer.

\section{Platform Capitalism and the Sharing Economy}

Platforms have become a resilient feature of the global economic landscape (Langley \& Leyshon, 2017). Platform capitalism emphasizes the intermediary logic and infrastructure of the 'platform,' a discrete and dynamic combination of socio-technical and capitalist business practices (van Dijck, 2013). Platforms enroll users (buyers and sellers) through a participatory economic culture that coordinates network effects, and mobilizes software code and analytics to 
create multi-sided markets. Platforms do not simply act as a conduit for connections but actively curates connections and infrastructure.

Choudary (2015) suggests that the distinguishing logic of platform intermediation relies on three distinctive operational aspects: a network community that consists of platform participants and fosters relationship between them; an infrastructure which is made of software, tools, rules and services; and data, which matches supply with demand using the platform. Smartphone mobile connectivity helps to unite users and do things that previously required time and a myriad of institutions (Morozov, 2015). Platforms offer a seemingly flatter and more participatory business model (Morozov, 2015) and ease of sign-up and direct participation between buyers and sellers generates a network effect, which Choudary (2015) suggests is the “new driver for scale” (p. 38).

The network is comprised of buyers and sellers who seemingly operate as equals in these transactions, whereas past such exchanges were marred by power and information asymmetries, favoring the seller (Langley \& Leyshon, 2017). Emphasized by Marxian political underpinnings, these models shift the focus from an economy of ownership to one of access, while still functioning within a capitalist frame (Kassan \& Orsi, 2012). Understood from this perspective, platform businesses act as intermediated 'rentiers' of the network (O’Dwyer, 2015) given that “the revenues prescribed by the platform business model amount to the extraction of 'rent' from circulations and associated data trails” (Langley \& Leyshon, 2017, p. 24). Lazzarato (2015) argues "rent” can be understood as distinct from profit and taxation, and where non-producers appropriate surplus wealth from productive workers (Gibson-Graham, 1996). In the case of Uber, both the passengers (buyers) and sellers (drivers) act as platform micro- entrepreneurs who rely on peer-to-peer rental services to match supply (available drivers) with demand (passengers 
in need of a ride). Uber takes a cut of the rent as their profit, which in turn is a share of the surplus value generated in real production.

Much of the existent literature on postcapitalism and the sharing economy highlights that communal ownership of goods and services could provide the foundation and potential for social and environmental benefits through the efficient utilization of shared resources (Martin et al., 2015; Botsman \& Rogers, 2010) and cooperativist experiences and subjectivities (see Cornwall, 2011; Dowling \& McKinnon, 2011; Healy \& Graham, 2008). In spite of the shared use of resources and buyer and seller symmetries, a nascent area of study that we take up with this paper is the ways in which these platforms permeate the lived experiences and working conditions of drivers operating within this postcapitalist space. In this study, we explore the motivations and experiences of Uber drivers navigating work within a platform-based business model. We are concerned with the ways in which these drivers understand and engage with Uber, an intermediated 'rentier of the network', and the implications for drivers who are participating in this form of productive labor without fully established regulatory frameworks safeguarding their employment experiences.

\section{Methodology}

\section{Uber}

As the sharing economy grows, ridesharing programs are effectively able to take advantage of mobile technologies and social networks (Cohen \& Kietzman, 2014; Kietzman et al., 2011). Founded in 2009 by Travis Kalanick and Garrett Camp, Uber Technologies Inc. is an on-demand ride-sharing service whereby customers/passengers are connected with various levels of service and private drivers using their smartphone application (Cohen and Kietzman, 2014). The service currently operates in 55 countries and 260 cities around the world (Davis, 2015). With over a million drivers worldwide, Uber Inc. is considered one of the fastest growing start- 
ups in history (Chafkin, 2015). Uber does not directly own vehicles but is part of the transportation-networking sector (Davis, 2015; Isaac, 2014). There are a variety of car options available for customers including Uber (also known as UberTaxi), which uses existing taxi fleets which are metered vehicles that are controlled by city regulators and UberX, a standard fourseater personal vehicle ${ }^{2}$. To access Uber, customers download a mobile application on their smartphones. The Uber mobile application "plays the role of matchmaker, matching a driver/car with a customer looking for a ride and taking a slice of the fare for providing the service” (Damodaran, 2014). The app allows for customers to track their driver in 'real time', thus providing a more reliable service compared with regular taxi companies who might not be using the same technology. As a result, Uber claims to maximize value to their customers both in terms of price and service (Cohen \& Kietzman, 2014).

Drivers wishing to join Uber face very low entry requirements, which our participants discuss in more detail. Our study was conducted in Toronto, Canada. Toronto-based Uber drivers are individual contractors. They set their own hours, are responsible for charging harmonized sales tax (HST) ${ }^{3}$ for every ride they procure, are responsible for the upkeep of their own vehicles and use their personal smartphones (or lease phones directly from Uber) (Arthur, 2014; Isaac, 2014). In addition to increased autonomy, without the licensing, plate fees and vehicle rental costs or commercial insurance fees that professional drivers such as taxi drivers face, many Uber drivers are potentially able to earn a higher income than taxi or limousine drivers (Damodaran,

\footnotetext{
2 Other options include UberXL which seats 6 passengers. UberXL cars are SUVs and minivans; UberSelect, Uber's entrylevel luxury service that seats up to 4 riders. Select cars are brands like BMW, Mercededs, Audi, etc; UberPOOL is the least expensive Uber. With Pool, you share your Uber with another Uber user and split the cost; UberBLACK and UberSUV is Uber's luxury service. Commercially registered and insured livery vehicles, typically a black SUV or luxury sedan is offered. Black is the most expensive Uber service

3 Independent service providers who make in excess of \$30,000 in taxable income are responsible for registering and charging harmonized sales tax (HST) of 13\% of the total cost of all goods/services rendered. The HST is then remitted to Canada Revenue Agency on an annual basis.
} 
2014). Uber has faced some harsh criticism for its ambiguous employment conditions and regulation avoidance tactics. It has been called "the most ethically challenged company in Silicon Valley” (Chafkin, 2015) and like many of the organizations in this rendition of the sharing economy, it has embraced a free-market, anti-regulation ideology (Isaac, 2014). Despite its claims of being "embedded in the fabric of the city" (Chafkin, 2015), Uber has been criticized for a "go-it-alone" (Cohen \& Kietzman, 2014, p. 291) approach, circumventing the local taxi and limousine commercial driver and insurance regulations, and has recently faced serious lawsuits for alleged inadequate screening procedures and auto insurance coverage (Davis, 2015).

\section{Uber in Toronto during summer 2015}

Uber launched its services in Toronto in 2014 and by the summer of 2015, with an estimated 19,000 Uber drivers, the company was already experiencing serious opposition from Toronto city council. This disquiet stemmed primarily around issues of ‘safety' given that drivers were not required to hold commercial auto insurance coverage, had not undergone any mandatory training, were not required to have their cars inspected, and were not mandated to have security equipment such as cameras in their vehicles (Jeffords, 2015; Owram, 2015). Some referred to these drivers as "bandit cabs" operating outside of the law (Johnston, 2015) and a reported 99 Uber drivers were charged with 198 bylaw offences pertaining to lack of commercial insurance (Johnston, 2015).

Uber's main source of competition was Toronto's taxi companies (Chen, 2015). Consequently, those in stark opposition to Uber and its drivers were not only city officials, but also Toronto's taxi and limousine companies and their drivers, who were operating under stringent and costly licensing, insurance and safety legislation and regulation. Those in strong opposition argued that Uber drivers were essentially doing the same work as taxi and limo 
drivers and should abide by the same by-laws to 'level the playing field' (CBC News, 2015). Despite the opposition, Uber was gaining momentum and growing in popularity with Toronto's young adult population and was the most used ride-sharing service (Criger, 2015). In a September 2015 debate about regulation issues, many Toronto city councilors acknowledged not only that "the people of Toronto want [Uber]" but also that "Uber is not going away" (CBC News, 2015). In December 2015 Toronto's licensed taxi and limo drivers took to the streets of Toronto and protested that the city should shut down Uber while council decided on which bylaws would apply to them (RT News, 2015). Many of these licensed drivers simply said that they wished for fairness and the enforcement of by-laws onto Uber drivers. In May 2016, Toronto city council voted in favor of Uber and created new by-laws to permit private transportation companies (PTC's) like Uber to operate in Toronto: drivers now must undergo a criminal background check, must have insurance of at least \$2 million for bodily injury, death and damages to people or property. Further, all rides must be booked through a smartphone app, with a $\$ 3.25^{4}$ minimum fare, no maximum fares and could mandate "surge" ${ }^{5}$ peak-time pricing (Toronto Star, 2016). While the City of Toronto maintained the requirements for taxis to have cameras and flashing emergency lights ${ }^{6}$, this was not a requirement for Uber (Toronto Star, 2016). Similarly while many of the by-laws for taxi and limo drivers were maintained, Uber's newly minted regulations helped to pave the way for them to also charge surge peak-time pricing.

\footnotetext{
${ }^{4}$ Canadian dollar

5 “Surge" peak time pricing refers to the way in which Uber sets price levels, responding to changes in demand and supply in the market. The idea is to attract more drivers during times of increased rider demand, but the high 'surge' charge is also an attempt to curtail rider demand.

${ }^{6}$ In Toronto, flashing emergency lights refers to a way in which taxi drivers can signal to the police, other taxi drivers or the public that they are in danger. The button is activated discreetly when the driver feels he/she may be in harm, with a flashing light usually at the rear or on top of the car.
} 


\section{Data collection and analysis}

The first and second authors of the paper conducted in-depth interviews with Uber and UberX drivers in Toronto between August 2015 and October 2015, sitting in the backseats of the Uber cars, recording the interviews on the same smart-phone technology that we used to hail the Uber rides. As we did not want to "lose the reality of the workplace” (Zickar \& Carter, 2010, p. 316), we conducted our interviews not only in the drivers 'workspace' (i.e. their personal cars), but also while they were working. This experience provided a way to capture informants' responses, and their immediate reactions to issues that arose when driving (e.g. traffic, jaywalkers etc.) in their cars. As such, the process of selecting informants was largely opportunistic. Once in their vehicle, we introduced ourselves as academic researchers who were conducting a study about the life-choices and work experiences of Uber and UberX drivers. We then asked if we could interview them while they drove us to our destination. We had a 100\% success rate, with all the 31 drivers providing written consent, agreeing to participate. It is important to note that the sample of interviewees is not intended to be a representative sample of Uber drivers all around the world; in this setting participants' engagement with Uber in the role of a driver is borne out of several local contextual factors. However, the sample is reasonably diverse, including experiences of a range of ages, professions, ethnicities and gender. Table 1 gives an overview of the 31 participants. All names have been changed in order to retain confidentiality and anonymity of interviewees.

The interviews ranged from 15 to 40 minutes and on average lasted for about 30 minutes. The interviews were recorded using our respective smartphones. The audio files were later transcribed verbatim. Informants spoke candidly about their experiences with Uber and other facets of their lives. They explained their motivations for getting into the business, the benefits of 
being an Uber driver and the challenges they faced at work. Many informants expressed concern about the uncertain regulatory environment in which they operated. Informants also shared with us their future plans, elaborating on their commitment and identification with Uber. It is important to note that the duration of our interviews was contingent on the overall duration of drive itself. Gold (1958, p.221) observed that when "[T]he observer-as-participant contact with the informant is so brief, and perhaps superficial”, it may not allow the researcher to dig-deeper into responses and might lead to the possibility of misunderstandings. We acknowledge that these brief encounters may indeed carry such a risk. While interviewing drivers in their site of work could be considered an advantage of this study, interviewing participants in this manner was not easy. We had to contend with music and traffic sounds, which often muffled our recordings. Admittedly these brief encounters were at times frustrating because they set up communication barriers that we were unaware of until we left the research site (i.e. the cars), and it was too late to probe further. Unlike traditional interviews where it may be common for the interviewer to "backtrack" (e.g. Gioia et al., 2012) and contact some participants to get some clarification on what they were saying, especially when it was time for interpreting the findings, this option was not accessible to us given the way in which we accessed our participants.

Our data analysis process was inductive and iterative. Each member of the research team listened to the first few audio recordings independently and conducted a preliminary scan of emerging themes. We regrouped as a research team to discuss our interpretation of the preliminary findings. This allowed us to refine our interview questions when we went back 'on site', which was especially important given the shortened duration of each interview. We used Gioia et al.'s framework (2012) to present the empirical findings in a way that demonstrated links between our data and emerging concepts (see Table 2 for the data structure). As a result, 
the emerging data structure provides "tandem reporting of both voices - informant and researcher" (Gioia et al., 2012, p. 18). We dealt with issues of multiple interpretations by engaging in an additional round of independent analysis, which gave us an opportunity to discuss any differences in interpretations and to establish inter-coder reliability (Atherton \& Elsmore, 2007). Using QSR NVivo 10, we independently coded the data. Our 'first-order' coding involved initial descriptive interpretations of the data. The open coding provided us a way to foreground our informants' interpretations and give voice to their experiences. This process led to the generation of the following themes: casual and fun, networking opportunities, control and flexibility, information and communication asymmetry, regulatory uncertainty, performance-inrole and oversupply and competition. We then abstracted these themes into two aggregate dimensions: 1) positive transition experiences and 2) anxiety-inducing transition experiences, which correspond to both the motivations to drive for Uber as well as their experiences in doing so. We then categorized our informants into three distinct groups and mapped these aggregate dimensions to the narratives corresponding to each driver group (see Table 2).

\section{Findings}

In this section we report on our participants' motivations and lived experiences of driving for Uber. This includes positive transition experiences as well as anxiety-inducing experiences, captured herein as motivations to join Uber and experiences driving for Uber. We structure our findings around the three distinct subgroups of drivers we found in our sample: (1) part-time drivers; (2) full-time (non-professional) drivers; and (3) full-time (professional) drivers. As the findings reveal, the power of scale generated by the network effect from the platform produces heterogeneity within users and their distinctive micro-entrepreneurial experiences correspond to a fusion of precarious encounters. 


\section{Part-time drivers \\ Motivations - why Uber?}

Part-time drivers were part of an Uber service provision known as UberX, which allows anybody with a private car that is a 2007 model or newer in good condition to register and drive as an Uber driver. The UberX service is packaged by Uber as one of its lowest cost ride sharing offerings. More than half of our participants (16 out of 31) belonged to this 'part-time' subset and were in the process of making voluntary transitions (e.g. changing employers, looking for new opportunities, going back to school etc.). Uber provided them with a way to earn extra income while they were exploring future options. For example:

Well, for now I'm just doing it part-time while I'm transitioning into a different salon. I'm a hairdresser but not working full-time right now. So I'm doing Uber while I'm looking around and it's pretty convenient. I think it's a good way to just make money while you're figuring out how to transition between careers really. Yeah, it's pretty perfect. (Sabrina, female, 25-30 years old)

I've been travelling this summer and as soon as I came back I realized that I couldn't really get a job because ... school's starting soon. I can't really get a job in a month, so I signed up for Uber and yeah; I came to the city last month. I'm going into second year [of my undergraduate degree] at the university and I'm actually trying to get into [graduate] business school. (Max, male, mid-30s)

Taken together, this group of drivers spoke about Uber being convenient given that they were in a stage of transition. This subset of drivers did not consider themselves to be trapped the way one might be when driving a taxi. The distinction between driving a regular taxi and driving for Uber was very important for this part-time group of drivers. Driving a taxi signaled an occupation with 'no end in sight' as illustrated by Dhaval, a college student who at the time of this study, had recently given up his job as a security guard to go back to school:

Uber is just right for me because I'm studying on the side. You know, I'm looking for some other job, a professional career. I'm working for that, not working to become a taxi driver, right? If I get into the taxi driving business it will be hard for me to get out of it. 
Because you're driving on your own, right, and there's no stress. Most people work at a main job and then do a second thing for fun, right? So while doing the second thing they're already fresh, refreshed, whatever word you want to use. But with a regular taxi it's a 12-hour shift for the guy. That is tough. (Ajeet, male, mid-30s)

In short, this group saw their work for Uber as a part-time endeavor from which they could generate some extra income, while working on potentially more attractive future opportunities elsewhere. They also felt they could 'get out' of Uber more freely compared with a regular taxi, which had connotations of a longer-term commitment and came attached with the somewhat unwanted occupational identity of a 'driver'.

\section{Part-time drivers' Uber experience}

Many informants within this category explained that they were attracted to Uber because of the ease of sign-up and low entry requirements. This was salient given that they did not intend to drive for Uber for very long. For example, at the time of the interview, Asim, a male in his midtwenties had been driving for Uber part-time for the past three months in addition to working a full-time job as an insurance broker. He states:

Anybody can sign-up. It's just a half an hour process. You go to the location and they ask you for your driver's license and a few other documents. You then fill out an application form and it is done (Asim, male, mid-twenties).

Of a similar age, Seth a university student, had only been driving Uber for two and a half weeks at the time of the study:

It is easy if you have a post-2007 registered vehicle, valid insurance and a legal work permit...one of my friends is (also) just doing it part-time for fun. He has a full-time job (Seth, male, mid-twenties).

Ease of registration meant that drivers could hit the ground running and begin earning an income.

The simple sign up process corroborated the casual or fun framing that many of these drivers expressed. For instance, Max, who is currently a student in computer programming, explained: 
I am doing this casually. I don't see this as a job-job, just something fun I'm doing on the side. I made 400 bucks yesterday and today (Max, male, mid-twenties).

This group of participants spoke about having control and flexibility over their schedules. Drivers have a zero-hour contract with Uber so they are able to work as much (or as little) as makes sense for them. Having complete control over their schedule enables drivers to take customers before and after other paying jobs or school courses or family care giving responsibilities. This part-time group highlighted their other roles and responsibilities:

I have a business on the side in video production. That's what I do. (Salman, male midto-late thirties)

I'm a dental assistant by profession. (I drive for Uber) because it's flexible hours and that is most important. I have a two year-old boy to take care of. Most other jobs require you to work for a fixed number of hours (say) 9-5. (Corinne, female, mid-thirties)

I have another job. I work in Ali Baba's restaurant. Yeah, so Uber is good, the schedule is good. You can do whenever you want. I do this like an extra job (Gauri, male, midtwenties)

Usually after work I do this (Uber). I'm a personal trainer...Yeah, so when I'm done with that then I do a little bit of this. I've got to pay the bills you know. (Badri, male, midthirties)

This (Uber) is my part-time job. I do construction full-time. I'm the owner of my company and [so when they need me] somebody calls me. For example, I have a few jobs and between the jobs, sometimes things are not ready on time. And so rather than wait, I just switch to Uber, at weekends usually. (Arif, male, mid-forties)

The extant literature suggests that Uber has contributed to "weakening of the permanent employment model” (Isaac, 2014, p. 15). However, accounts of this group of participants, at least at face-value, suggest that in these times of a depressed labor market Uber provides an opportunity for individuals to remedy economic pressures, uncertainty, and precariousness and to supplement their income in a fun and flexible way. These drivers do not strongly identify with the occupational role of being a driver, nor do they have to. They see driving simply as a convenient way to bolster their income. Without imposed deadlines or anticipated hours of work 
dictated by Uber, they can self-organize to manage their time, which is crucial since they have other pressing roles and responsibilities. These drivers highlighted how Uber does not mandate working hours, but yet in order to make Uber fit with their other roles and responsibilities and to hit in-demand peak hours, they imposed their own working hours.

In addition to the ease of sign-up and scheduling their time, drivers also discussed the importance of being able to select their customers. Drivers can turn down rides in response to a rating system procured by the Uber app that aggregates feedback from other drivers about the customer, based on star-ratings. For example, Max, a university student in his mid-thirties explains a recent situation where he had provided an unfavorable star rating:

Around $7 \mathrm{pm}$ yesterday, I had this passenger who was not drunk, but pretty crazy. You can't be touching the drivers. He touched me, which was inappropriate. So I gave him a one star. I should have reported that for sure. I might do that when I get home. Warn other Uber drivers that this guy is touching drivers (Max, male, mid-twenties).

Max had not gone as far as to report the customer formally, but used the one-star rating to alert other drivers that the ride was problematic. On the receiving end, drivers react and respond to these star-ratings in helping them decide which rides to take. For example, Salman, a male in his mid-thirties who also works in video production stated: "I mean if I see a passenger that's below four [out of five]; I don't have the patience to go there.”

Although drivers have no opportunities to connect with one another through formal organizational channels, the star-ratings act as shorthand for drivers to communicate with each other and provide instant feedback about customers. The star-ratings also pertain to drivers. Customers rate their drivers on a similar scale also using the app. Taken together, drivers have control over when they want to work and which customers they choose to service. So long as they themselves maintain an adequate star-rating score, they can continue to drive for Uber without penalty. Across the three groups, our participants did not voice challenges with this 
minimum expectation. Part-time drivers emphasized the joy of driving and meeting people, sharing ideas with the community, and receiving social support and run ideas and feelings by customers. Their personal cars gave them the opportunity to meet people outside of their immediate social circles. For example:

Well, I love driving anyway, so this is just a hobby for me. I've met a wide array of people. I love meeting new people because you never know who you'll meet and how that person can benefit you or you can benefit down the road at some point. (Nick, male, mid-thirties)

In the future I might become a full-time dental assistant... I'm also taking advantage of driving around just to look around and explore. I'm also talking to different type of people and customers everyday (Corinne, female, mid-thirties).

I've been driving some interesting people. I've been driving some big names in the film festival, like working on the film festival. Some bar owners, some suits that were in the financial district, families, people that tell me their stories, so it's been really sweet. You just talk to people. If you open up they'll open up. You learn something every day. (Max, male, mid-thirties)

Here, the use of 'fun' and reminder of the 'part-time' status illustrate how our informants refrain from developing a lasting identity with Uber or their role. This group of participants emphasized that their Uber driving was something temporary and therefore did not hold the same expectations they might have for another job. Such a view seemed to de-intensify and casualize the working relationship between Uber and drivers. By eroding a formal connection to the occupation or organization, drivers also reframed their own expectations and assumptions about Uber, what they should expect in terms of pay and support from the company. This did not mean that drivers were free from frustration. Khazin states:

When you get hired they don't tell you about the $\$ 1.50$ they deduct for each trip. They say we just deduct $20 \%$, but if you pay attention the fares are less than ten bucks for most of the rides, especially when you are in downtown, and $\$ 1.50$ is $15 \%$ of the fare plus $20 \%$ and that is $35 \%$. $15 \%$ goes for the gas, so the reality is $50: 50$, but when they want to hire they say come and work for us on a 20:80 basis, but then they don't mention that it is actually 50:50, the bottom line (Khazin, male mid-forties) 
Other drivers, such as Jordan, a manager at an ad agency expresses frustration over not being able to communicate directly to head office and lack of clarity in answers that are provided:

There are some issues still between Uber and the city about insurance....and those things. Uber doesn't have any call center, that's a bad thing. You know, always the communication is through email or iMessage, so whenever I ask them a question, they don’t give you any clear answers (Jordan, male, mid-forties).

These excerpts reveal uncertainty, confusion, and at times frustration about understanding Uber's policies and ways of communicating. Yet, without a formal connection to Uber or the role, this subset of drivers carried on driving for Uber, without significant probing or contestation. Their complaints were feeble, as it was perhaps not worth the time to interrogate further or push for change given the short-term horizon that they envisioned for themselves.

In summary, the part-time group of drivers worked for Uber in conjunction with their other roles and responsibilities. With control and autonomy over their schedules, the part-time drivers are seemingly able to juggle competing responsibilities and maximize their earning potential. Notably, this group of drivers had strong future-oriented aspirations. They were at pains to explain that they were somewhat detached from their 'Uber taxi-driver' identity. They considered their involvement with Uber a temporary, part-time fix until their future aspirations materialized. There was a strong sense with this group that they were agentic and could quit working for Uber at any time. Uber was one way to fund their imagined future and continue living their prescribed lifestyle without having to cut down or cut costs. Driving for Uber was not considered a permanent or a primary source of income but a welcome source of income nonetheless. They did not see it as a traditional job, viewing it more as leisure. The experience and attitudes of this group of drivers raises interesting issues about work and the monetization of 
downtime in late capitalism, wherein individuals are actively thinking of alternative ways to earn money outside of what they would consider to be their primary job or career.

This group’s monetization of downtime - what Ross (2013) refers to as playbor, combining play and labour together - underscores the need for work to be fun, or at least less demanding than other work roles. The part-time drivers spoke about driving as something that was free from the obligations of work but also more structured and personally fulfilling than pure entertainment. It was framed as a non-necessity, a choice that can be voluntarily undertaken. Gelber (1991) indicates that from this vantage point, work resembles a hobby. One is able to do their hobby whenever they want. If considered as a form of 'hobby work' we suggest that parttime drivers take on the role of 'Uber driver' for many of these reasons: it is seemingly enjoyable, they are able to be productive, they are able to voluntarily take it on when and how they want to. Uber also is a form of work, like a hobby, that cannot be taken away from a person. Unlike jobs, which are arguably "only reliable until the moment they disappear” (Kassan \& Orsi, 2012, p. 6), the hobby framework eliminates the possibility that it might go away. A hobby can be quit, but one can never be laid off from it (Gelber, 1991). That is not to say that driving for Uber is pure enjoyment (see Rogers (2015) for work on the frustrations and social costs of being an Uber driver). Rather, the leisure framing of work highlights choice, non-essentiality, and social aspects of busying oneself. Here, we see drivers emphasizing that Uber provides them with a flexible and autonomous schedule, which they fill up with more work. This is an important finding because it forces us to consider the question: "There are still only twenty-four hours in a day. When "downtime" is turned into work time, and that work time is unpredictable and low-paid, what happens to personal relationships? Family? One’s own health?” (Reich, 2015). 


\section{Full-time (non-professional) drivers \\ Motivations - why Uber?}

Nine participants in our sample drove for Uber full-time as part of the UberX service provision.

They had no prior experience of driving taxis, but Uber was now their primary source of income following periods of unemployment or/and debilitating health conditions. Put differently, they turned to Uber because they had no other employment opportunities. For instance, Aaron describes joining Uber after being laid off:

[I've been driving for Uber for] a year or so. About 12 or 14 months ago, I was made redundant at my previous job. I couldn't find a job after that. Once you're close to 55 and you've lost your job they won't let you enter the market. It's a kind of national tragedy. (Aaron, male, late-fifties)

In his account, Aaron, an immigrant to Canada in his late fifties alludes to his age as being a reason for not only losing his job but also being unable to continue his career as a chemical engineer. He goes on to explain that he feels he cannot take on too much stress because he is diabetic. The loss of his job, coupled with his current health situation compelled him to start driving for Uber. Britesh has been driving for Uber for four months after a recent layoff:

Earlier I worked at a company, which closed and moved to the US. I was in the shipping and receiving area... I'm looking for another job but it's not easy to get a job (Britesh, male, late-forties).

Fahrid turned to Uber after suffering a heart attack and running out of options:

I was a cost accounting manager in my country, so when I came here in 2000 I went to college, got some Canadian certificates. I then worked at a friend's office. He was running accounting services. After a while because I knew a lot about this business I opened my own office and my friend sometimes helped me, sent me some customers and I also started getting other customers. Then I got a heart attack. I went to the hospital and they operated on me and I had four bypasses. I then had a stroke ... they kept me unconscious for two months to reduce the brain damage. After two (more) months of (expensive) rehab all my business and money was gone. So after that I started going to my friend's office to work, but couldn't focus on anything anymore. So I told my wife "I cannot work anymore in my field, so you should go to college and learn something." So she went to college and is a very good dental assistant and... actually all financial things are on her. I was just making a little money working in my friend's pizza store for two- 
three hours. Then he told me about Uber, so I applied and started working for Uber (Fahrid, male, late-forties)

Fahrid's story details coming to Canada and experiencing the challenges associated with immigrating, trying to create a network, establishing Canadian qualifications, and securing employment, all of which he appeared to have done successfully. His economic stability was however seriously threatened with the heart attack and subsequent health issues that he encountered. Driving for Uber was thus the last resort in the quest for a steady income.

In the emotionally wrenching stories of this group of drivers, there is a common theme of building up a professional profile and then a sudden loss of livelihood. In each instance, Uber provided an opportunity that transcended the structural barriers of age, gender, education and ethnicity. Thus, this subset of drivers who might otherwise be excluded from the labor force after a long hard fight to participate in it in the first place saw Uber as one of the few available opportunities for paid work.

\section{Full-time (non-professional) drivers' Uber experience}

Unlike part-time drivers who took rides in between other roles and responsibilities, this subset of drivers drove for Uber as their single source of income. They organized their time and schedule based on their understanding of high-traffic times:

At 7pm I'm going to quit, so it is just one more hour to go. I started working at $7 \mathrm{am}$. Actually, now is a good time to work, but I'm too tired. On Saturdays, of course it's very good to work from 7am to 10pm. (Fahrid, male, mid-forties)

Well, I'm doing Uber from 11am-1pm. I might then drive till 3pm or $4 \mathrm{pm}$. It just depends. If it's busy this afternoon I might just keep driving until 8pm or so because once I'm here, I might as well continue. (Megan, female, mid-forties)

[Driving] in the morning between 6.30 and ten o'clock is a little bit busy and afternoons after three until seven... I take a break between when it's not rush hour. If it's busy, I continue for nine, ten hours (Britesh, male, mid-forties). 
As such, drivers' schedules are flexible in that they are determined by them but are quite constrained by external demand. The hours are often long but drivers try to schedule their time on the road to make the best fares. As Uber charges a fee per ride rather than a flat fee per week, drivers have the flexibility to work when it suits them and take time off as needed. Within this subset, drivers were more knowledgeable about on-going insurance debates pertaining to UberX and commercial insurance than the part-time drivers. For example, Theo had the first author sit in the passenger seat of his car out of fear of receiving a fine of $\$ 5,000$, which was being issued to drivers without commercial insurance coverage:

Yeah, I was busy today because there are not many drivers on the road now because yesterday they gave out 280 tickets to UberX drivers... Uber is absorbing the ticket cost, but they just emailed us today saying ask the riders if they can sit beside in the passenger side (Theo, male, mid-thirties)

I know [Uber is] talking with the insurance companies and they are going to come up with an insurance soon. (Khazin, male, mid-forties)

We're going to follow the rules. The city says we [Uber] have to get commercial insurance. What can you do? You have to get it otherwise ... but they have to change the price. Now [the work is] very cheap. Now Uber, they're going to take $25 \%$ plus insurance. (Britesh, male, mid-forties)

Also, unlike the part-time drivers, few had significant complaints about the company or current fee structure. For the drivers within this subset who were experiencing structural unemployment and underemployment, Uber, albeit not perfect, was still better than the alternative (not working). This however does not suggest that drivers did not experience challenges. Some of the drivers within this subset felt uncomfortable with driving, the road conditions, and GPS technology that were being used. Fahrid for example expresses his concern:

I learnt to drive here [downtown], I am better than before, but I am not very good. I'm really scared because now it's good, but when it's winter it's going to be pretty hard work. 
Michela, from Winnipeg who recently moved to Toronto and was driving for Uber full-time expresses similar concerns about traffic:

Yeah, they say Thursday, Fridays and Saturday nights are when you make the big bucks. I kind of did it one night from like 11 to 2am and it is a little more hectic. Like I think other drivers are like zooming around and it's just a little bit... I don't know, more hectic (Michela, female, mid-twenties).

Britesh adds:

Actually for me [driving] is not easy. I have to work. The customers sometimes say addresses but they are a little bit confused. Sometimes the customers are on the other side of the street. The work is not easy. You have to concentrate to drive. I have responsibility. (Britesh, male, mid-forties)

Some of the drivers within this category experienced the same flexibility with scheduling as their part-time counterparts. Yet, they based their schedules more on the customer demand. Further, as illustrated, drivers such as Michaela and Britesh did not express their enjoyment with driving as much as the part-time drivers had. Instead, they experienced increased pressure and anxiety due to having less confidence driving in the bustling downtown core. To note, drivers such as Britesh and Fahrid found the road conditions challenging because they were living in suburban areas and were not accustomed to the pace of traffic.

Overall, this second group of full-time (non-professional) drivers drove for Uber to make ends meet during times of involuntary work transition triggered by job losses or/and health issues. The experience of this group is particularly poignant since they had few employment options, more constraints and limited individual agency to get out or get something better. It would seem that despite not seeing themselves as occupational taxi drivers, they were stuck with driving for Uber just to make ends meet. On the positive side, Uber was an option that did not discriminate or further perpetuate the structural unemployment that they were already experiencing. Thus, this group of drivers voiced few complaints about the company or the 
current fee structure, appearing rather grateful for the opportunity to be working gainfully at something.

\section{Full-time (professional) drivers Motivations - why Uber?}

Six of our participants were professional drivers. They explained their decision to drive for Uber in terms of the intensely competitive taxi business landscape. Hatib a limo driver, shares that he was driving for Uber out of necessity: “It's been slow for [everyone]. It's great that there’s Uber otherwise I’d probably have to start looking for another job. It has been that slow” (Hatib, male, mid-twenties). The notion of an expanding competitive marketplace is further elaborated on by Hani, a taxi driver: "People are choosy. Now people have choice: transit, cabs, Uber, UberX. Earlier, they had very few options” (Hani, male, mid-thirties). With this increase of options, the professional taxi drivers in our sample spoke about working for Uber as a way to supplement their taxi income. They also highlighted the advantages Uber offered when compared to the exploitative work conditions imposed by regular taxi companies. Aly, an ex-taxi driver now driving exclusively for UberX explains:

I made more money driving a taxi because I get the meter amount. Uber is $15 \%$ cheaper than taxis so it's discounted. So it's more money in a taxi, but the one thing I don't like about taxis - I cannot take a day off. Like if I want a day off they always tell me "Okay, you can take a day off, but you have to pay us.” So I used to pay $\$ 550$ a week to drive a taxi...I want a day off, they say, “No, you have to pay us $\$ 550$. We don’t care if you work or you don't work. That's all your business.” Now I drive for Uber. About two weeks ago I had a barbecue party. I went out with my friends somewhere and we had a barbecue party, and I took Sunday off (Aly, male, late-forties).

Hani elaborates on the taxi fee model:

Right now the license plate is $\$ 2500$ a month to rent. Plates, then car, then insurance. Insurance is too high, like around $\$ 10,000$ per year insurance. So lots of expenses, about $\$ 3200$ per month. Even if we don't have any business [the cab companies] don’t care, they take their money (Hani, male, mid-thirties). 
With the traditional taxi business model, fees are incurred regardless of how many rides are procured. Thus, as explained by Aly, the rental fee model acts as a disincentive to take time off. With Uber however, fees are incurred on a per ride basis, providing more flexibility. Drivers are not penalized for time off. This group of professional drivers explained that by switching to Uber, they were able to recoup and cover some of the costs related to driving for a regular taxi company. In sum, participants within this category saw driving as their profession. They had turned to Uber with the hope of reaching a broader customer base and mitigating the ongoing financial burdens of their taxi driver life.

\section{Full-time (professional) drivers' Uber experience}

Participants in this group noted that although Uber was popular among customers it was harder for drivers to make money:

See over there [pointing to pedometer] - I drove 418 kilometers yesterday. In a taxi you have to drive only 100 to 150 kilometers to earn the same amount of money. Uber is cheaper, right, so we have to run more. ...but it's okay. I don't have a complaint. The best thing is that you can drive whenever you want to drive. People say Uber, Uber, Uber. Uber okay, but the people driving are not making a lot of money. It's customer friendly I guess! (Ira, male, mid to late thirties)

They also discussed their experiences in relation to the other two groups of drivers identified in

our study. These two groups drove the low-cost Uber service version known as UberX:

Many people don't take Uber Taxi because UberX is so much cheaper. So that's where taxis are losing, you know. Even limo drivers are losing money. Especially when you don't own the car and you're driving for somebody else then you can't really do UberX (Ahmad, male, mid-forties).

Hatib adds:

The problem is UberX. They didn't follow the city by-laws or other stuff. They didn't follow anything. Any private car can be UberX. The city doesn't want to make more [taxi] plates or have more cabs on the road. So now how many cars are on the road like UberX? Nobody knows. Probably thousands (Hatib, male, mid-twenties). 
This group of drivers was also aware of the insurance issues, with uncertainty of how this translates in case of an accident. For example, Ira shares:

You know, it's a problem if an UberX driver is in an accident. If there is a customer, the customer is covered for $\$ 5$ million in insurance coverage. I don't know what happens to the driver though. I think that if the government wants to keep Uber, they must make all this law, I guess (Ira, male, late thirties).

Other drivers shared additional complaints about the incremental hike in fees. For example, Iyas explains, "In the beginning they just charged 10\% from us and right now they're charging $20 \%$ from us”. Ira adds:

Well, I heard today when I actually went to this meeting in an Uber Taxi that he has to pay $20 \%$ to Uber and it used to be only $10 \%$ if you were a taxi driver and now it's $20 \%$ just like UberX, but the problem with the cabs is that they also have to pay their own dispatch and they also have to pay for the lease of the plates and the car. So, you know, all I could think to myself, this guy doesn't sound like he's making any money. It sounds like he's losing money (Ira, male, mid to late thirties)

In sum, this set of full-time professional drivers spoke about the flexibility Uber offered and the ways in which they could potentially bolster their income using their taxicabs. They were working for Uber to keep up with the changing landscape and to mitigate the impact of the exorbitant weekly rental fees charged by traditional taxi companies. Thus, they were able to find alternative ways to earn income using the same rented, licensed and outfitted taxicab. As professional drivers, this group also had commercial insurance coverage, unlike the other two groups' whose insurance requirements were mired in regulatory ambiguity. These drivers spoke about the challenges they experienced making ends meet with the increase of UberX cars on the road while still trying to pay their weekly taxi fees. However, competition and over-supply of Uber drivers - thanks to the other two groups - were beginning to seriously squeeze their daily incomes. Uber offered a disruption to the traditional taxi business, charging a per ride rental cost rather than a fixed flat rate as seen with taxis. In doing so, many of the drivers articulated 
grumblings about the per-ride fee increases but few had bigger complaints to voice as the per ride fee was still more palatable than the flat fee taxi costs.

\section{Discussion}

In the above analysis, we focused on the motivations and lived experiences of Torontobased Uber drivers who act as platform micro-entrepreneurs. We respond to a call by Langley and Leyshon (2017) to add to this burgeoning field of platform economy research by detailing the particular coming together of socio-technical and business practices in concrete terms for specific enterprises. Specifically, we examine Uber. Our 'three-group' typology sheds light on the nuanced life circumstances that prompt individuals' engagement with Uber as drivers, and provides salient insights into their working lives. As Orsi (2013) notes, "Uber is a capitalist firm, multinational in scope that employs wage laborers." It does not operate in terms of cooperativism, where the company is owned and directly operated by drivers. Instead, it provides drivers and consumers with single-use access and transactions as opposed to ownership or pooled communal resources.

Our findings illustrate why and how in turbulent economic times riddled with financial insecurity and instability, individuals from a range of backgrounds may gravitate towards the platform-based sharing economy in their quest for financial independence. The Uber business model appears to be ideally suited to support the particular needs and schedules of individuals in transition (i.e. those that are switching roles and jobs either voluntarily or involuntarily). While transition, marked by liminality, can be conceived as being "painful” (Czarniawska \& Mazza, 2003, p. 272), our interview accounts suggest that such a liminal space can also offer a sense of freedom and possibility (Czarniawska \& Mazza, 2003). Uber is positioned as a safer place to 
pause from economic hardship and transitions, appealing to different types of drivers by supporting their unique and difficult personal circumstances. This suggests a plurality of precarious experiences that are constitutive of this new era of post-capitalist work. Across the typology, flexibility was a key theme, which was further amplified by Uber's lack of rigid or formal bureaucratic rules and policies. Instead of top-down managerial control, drivers were kept in check using customer ratings and received sanctions for underperformance as determined by customers. These reputational devices of ranking ride experiences help to stabilize user expectations by providing information to one another via the platform (Morozov, 2015). Here, reputation functions as both a form of capital and discipline within digital economies (Arvidesson \& Peitersen, 2013).

Digital ecosystems rely on software, hardware and other socio-technical materials (Beer, 2013). We suggest that digital ecosystems summon-up not only the popular passions and interests of the 'platformed masses' (Lovink \& Tkacz, 2015, p. 14) but also their popular insecurities and precariousness. Although platforms facilitate employment opportunities for the under-employed and unemployed, it is no secret that they have been subject to considerable critique for their perceived role in the degradation of work and working conditions (see Friedman, 2014; Langley \& Leyshon, 2017). Platforms bolster the 'gig' economy, providing a new outlet for short-term, casual or zero-hour contracts. For drivers, this precarious employment, dubbed more broadly as 'apploitation' (Calloway, 2016), means that while drivers may not be able to lose their jobs with Uber, but equally, they also may not be able to get ahead, save for retirement, receive adequate training and development, and receive basic insurance coverage or worker compensation benefits. Drivers shift perceptions of control from that of an employer onto themselves - they perceive themselves as being in the driver's seat (pun intended). "When 
bidding for work via platforms individuals may find themselves in a race to the bottom and if successful, will do so as self-employed contractors” (Langley \& Leyshon, 2017, p. 30). However, as our study highlights with the full-time non- professional drivers, Uber also creates employment opportunities that might not have previously existed, thus simultaneously existing not only as a platform of precarity, but also one of opportunity (Gillespie, 2010).

In this study, we examined these opportunities and by focusing on the lived experiences of the three groups of drivers, we provided insights into different dimensions of precarious work in the sharing economy as facilitated through platforms. However, the lived experiences of the three groups of drivers clearly highlight the fault lines. In spite of the flexibility and ease of signup, many drivers did not think Uber was a lucrative way to earn an income, given the amount of driving that was needed to keep up with operating costs and the amount of time needed both on the road for Uber and in other jobs to earn a decent income. In particular, the second and third groups seemed stuck between the proverbial rock and hard place, where driving for Uber was the best available option for them in their current circumstances. For some, driving for Uber acted as a self-preservation mechanism that boosted their hope that things would perhaps get better, but at least not worse. Others remained skeptical and felt the ultimate 'winners' of this working arrangement were the customers and the organization. This positioning is salient for two reasons. First, it builds on the motivation that individuals have to contribute to society in a meaningful way by taking care of themselves and their families on their own terms. Second, by being positioned as better than the alternative (i.e. being unemployed or driving a taxi) it suggests that Uber does not have to be a 'good' organization but just better than what else is on offer to be positively recognized. Thus, drivers appeared grateful to Uber even when voicing critiques, since it was perceived as being better than the alternatives available. For instance, the fees deducted by 
Uber were for the most part seen as nominal especially when compared to taxi fees and thus, largely unquestioned.

Overall, drivers were acutely aware of the disadvantages of the work, the financial difficulties and basic employment benefits that they forgo. Yet, rather than complain or quit, they seemed to reshape their own expectations. The part-time drivers looked into the future and thought about what was next for them, reminding themselves of the temporary nature of their work with Uber. These drivers were in transition, upgrading their skills with more education or transitioning into new jobs. Uber provided a semblance of financial stability, and they had few critiques of the organization, given that they enjoyed driving and were using their own cars. It seemed that investing in a critique would render over-commitment to a job and a role they did not intend to stay in for long! As noted earlier, for full-time (non-professional) drivers Uber was a saving grace from the throes of unemployment. While they did not strongly relate to their driver-identity, this group was grateful to be working and making some money in their driver role. This group reminds us that, "We are all already economic subjects, shaped by the dominant discourse of capitalist development, with desires for employment, wealth, or entrepreneurial activity. We wake up in the morning wanting a job, not an alternative economy.” (CEC, 2001, p. 33). The third group (full-time, professional drivers) were trying to keep their head above water in a crowded and competitive marketplace, where seemingly anyone could sign up and start taking fares. This group of drivers had the advantage of taking taxi fares (where customers could flag them on the road or call in through dispatch) or through the Uber app. Although these drivers had the greatest opportunity to earn income, they were also exposed to the greatest threats, feeling the biggest squeeze from the imbalance of supply of drivers and demand of customer rides. 
None of the drivers in our study spoke about a long-term future with Uber. Instead, driving for Uber, across each type of driver group represented in our sample was a just-for-now remedy. Although they did not discuss a foreseeable future with Uber, the majority of drivers interviewed, specifically within the category of part-time drivers, did not convey a sense of pessimism, fear or vulnerability pertaining to physical or legal risks as found with other studies of workers within the sharing economy (see Roger, 2015). Our findings hint that negative experiences might have been mitigated by the drivers' perceived sense of control over their working conditions. From a methodological perspective, this neutralization of experiences could have also been based on participants' own attempts at impression management, knowing that we were researchers with a primary interest in studying their working experiences. They may have thus put a glossy spin on an otherwise precarious, tumultuous and challenging low-wage work most often performed by those that faced serious underemployment: young workers, immigrants, and women. Within each category, driving for Uber appears to be 'safe' and ongoing, steady form of 'work'.

In this study, we have explored the sharing economy as facilitated through platforms and the work experiences of Uber drivers. Yet, we note that there is considerable debate and disagreement about what constitutes the sharing economy and how to interpret its significance. This may be because there is not a singular sharing economy. Rather, the sharing economy consists of a variety of postcapitalist forms of organizing. On one end of this spectrum are appdriven firms like Uber, Lyft, Airbnb and Taskrabbit. These platform-based businesses represent intensified or hyper capitalism as non-producers (e.g. Board of Directors and other shareholders within the businesses) benefit by receiving the surplus value generated by workers. On the other end of the spectrum, the sharing economy can be viewed as anti-capitalist in nature, comprising 
of a plethora of activities that may include worker cooperatives, community gardens, food, home and renewable energy cooperatives and a variety of other forms of collective ownership and management (Botsman, 2013; Gibson-Graham, 1996; Orsi, 2013). From this perspective, the sharing economy offers alternative ways to think about how goods and services are used and how surplus value is maximized and distributed through local sharing schemas whereby producers benefit and distribute the surplus value that is generated (Cohen \& Kietzman, 2014). To date, much of the literature on work experiences within the sharing economy has examined the worker subjectivities within this anti-capitalist or cooperativist setting (e.g. CEC, 2001; Gibson-Graham, 1996, 2001), thus ignoring a salient and durable feature of the current economic landscape, digital platforms.

Postcapitalism, as conceptualized by Gibson-Graham (1996, 2001, 2006) and later by other researchers operating within The Community Economies Research Network (CERN) and the Community Economies Collective (CEC), seeks to re-image the economy to include and account for non-capitalist forms of economy. From this perspective, economies are diverse and in a process of becoming (Gibson-Graham, 2006). Within this process, alternative economies, their subjectivities and working practices must be represented as viable and functioning alternatives (Gibson-Graham 2006). This involves embracing economic difference and diversification, rather than replicating sameness and capitalist ideology. Orsi (2013) claims, “You can't remedy today's economic problems by using the same business structures that created the economic problems”. Sharing by way of pooling resources and eliminating personal ownership might, "liberate society from the practices of hyper-consumption" (Martin et al., 2015, p. 240). Sharing from this communal or cooperativist perspective would provide a more equitable distribution of resources and emphasizes the collective good and mitigates class 
exploitation. If produced and distributed among workers rather than non-producers, exploitation diminishes.

The sharing economy from this cooperativist stance could be seen as a response to the imbalance between production and consumption if the surplus value that was created by maximizing the value of personal resources (homes, cars, etc.) was communally created and distributed. Orsi (2013) refers to this as platform cooperativism where, worker-owners would receive the surplus value currently accruing to businesses like Uber. Here, the sharing economy may be envisaged as post-capitalist with emphasis on the 'post' denotes the notion of 'alternative' economic structures and business models beyond or instead of capitalism (e.g. Parker et al., 2014; Wilson, 2013; Wright et al., 2013). This version of the sharing economy could "move the needle in assisting a radical shift in global and local economics towards sustainability" (Cohen \& Kietzman, 2014, p. 294). This conceptualization of the sharing economy aligns with Kassan and Orsi's (2012) characteristics of the 'new economy', marked by casual, spontaneous one time transactions, agreements that rely on the local availability of goods and services, large scale infrastructure including multiple stakeholders, regulatory bodies and government.

Consequently, when discussing Uber under the umbrella of the sharing economy, one continues to speak of a market-based, platform economy whereby money is exchanged for goods and services and the potential for exploitation of workers is high since they are bereft from benefiting from their own surplus value creation. Booth (2013) contends, “If this is 'sharing', we might classify all sectors and industries as being part of the sharing economy.” Instead, what we see with this rendition of the sharing economy is the rise of rent-seeking capitalism established through the conversion of small-scale personal property into capital. Here, postcapitalism, with 
emphasis on 'capitalism,' suggests intensification or an upsurge of capitalist ideology and practice. Morozov (2013), for example, argues that the sharing economy is "neo-liberalism on steroids”. It is seen as a hyper-individualization of the employment relationship, with workers assuming the burden and risks of work, while using their own material resources and equipment. Postcapitalism from this lens, is largely concerned with how organizations can become hyperlean, hyper efficient and more profitable (Kessler, 2015). Organizations operating in a sharing economy can end up getting pressured to mimic the market-economy's logic of other, 'successful' organizations which operate within mainstream economic models (Martin et al., 2015).

The interpretation and significance of the sharing economy is highly debated. Orsi (2013) sees the anti-capitalist potential in the sharing economy because of her focus on cooperatives rather than platform-based corporations like Uber. Kessler (2015), on the other hand reaches the conclusion that the sharing economy is intensified capitalism by focusing on platform- based businesses. They reach different conclusions because they are in part, talking about different things related to the distributive nature of surplus value creation, class and class exploitation (Gibson-Graham, 2001).

In this article, our understanding of Uber as an illustration of the sharing economy illustrates these post-capitalist conjectures, 'super-sizing' and hyperbolizing it, rather than creating a distinct alternative from it as Uber drivers do not directly benefit from their own surplus value creation. This is perhaps neoliberal individualism and hyper-capitalism at its finest and a far cry from Orsi’s (2013) call for a sharing economy based on cooperativism, collectivism and the greater good of the group. None of our informants came close to hinting that Uber is an 
alternative to capitalism, echoing Fournier’s (2002, p. 189) claim that perhaps there “aren’t many alternatives to capitalist corporations”.

Taken together, this typology of drivers highlights that within postcapitalism various precarious circumstances are produced. Uber, as a hyper-capitalist rent-seeking enterprise has concocted a way to appeal and appease a variety of workers struggling to stabilize themselves within an increasing unstable economy and capitalize on the surplus value being created through these different episodes of precarity. For each subset of drivers, Uber was seen as something better than nothing (i.e. unemployment and underemployment). The drivers' own explanations had a strong relational dimension. For instance, the part-time drivers felt liberated and free to opt in and out of Uber unlike the drivers who only had Uber to fall back on. The full-time (nonprofessionals) obviously felt better off than being unemployed or driving for a regular taxi company. The professional drivers felt Uber offered a reprieve from traditional taxi companies and their rigid flat fee structures. They also felt more protected with the security of commercial insurance. Thus, Uber simultaneously appeals to multiple groups, and works well for them in a relational sense. From the drivers' perspective, Uber is better than the alternatives in an unsteady and precarious world.

The Uber drivers within our study made the decision to work for Uber and use their own resources to do so, trying to "construct a hoped-for future in the present” (Chatterton \& Pickerill, 2020, p. 476). Uber may not be an alternative to capitalism; it has most certainly revealed cracks in the current capitalist framework, preying on and succeeding by way of innovation that is thriving in regulatory ambiguity, turning employment and insurance regulations and governance on its head, and using a spectrum of precarious workers. Future research should continue to investigate the ways in which legislation, local authorities, and intermediary organizations such 
as insurance companies are reconfiguring to keep up with these new strains of hyper-resistant platform capitalism.

\section{Concluding thoughts}

Postcapitalism within the context of platform-based sharing economy as we have revealed, may not be an anti-capitalist alternative but it has presented new challenges, insights and configurations of capitalism. One such expression of postcapitalism that this paper has reflected on is the work and lives of Uber drivers. Driving for Uber is a personalized, commercial endeavor, established in the dark spaces that current business models and legislation are only starting to venture into. It does not remedy threats to instability, precariousness, or work intensification. Rather, for some drivers, it exacerbates these realities. Some, like Orsi (2013) want so desperately for the sharing economy to be an emancipatory force, a salvation. Instead, as an illustration of being an alternative sharing economy organization, Uber yields great disappointment. It mimics and mirrors the system that so desperately needs to be fixed with nonproducers still benefiting from the hard-earned surplus value generated by various producers. Platform cooperativism (Orsi, 2013) within this economic landscape may however be viable in at least some parts of the world. In major Indian cities for instance, taxi-drivers' unions are poised to launch an app-based tax-service following a cooperative model in direct competition with companies like Uber (see Chakraborty, 2017; Kashyap and Lulla, 2017). Thus, although Uber may not (yet) reflect an alternative capitalist system where producers redistribute surplus value to the collective group of other producers, the business model may spur fairer renditions of the sharing economy that are closer in spirit to Orsi's (2013) notion of platform cooperativism. With Uber, we are reminded that the 'alternative organization' is still something we are yet to witness 
Postcapitalist precarious work and those in the 'drivers"' seat

- it is still in a state of 'becoming' rather than something that has become (Gibson-Graham, 1996). 


\section{References}

Arvidsson, A. and Peitersen, N. (2013). The Ethical Economy: Rebuilding Value After the Crisis. New York: Columbia University Press.

Arthur, C. (2014). Why the sharing economy could be the internet's most divisive revolution yet. The Guardian. Retrieved from http://www.theguardian.com/technology/2014/dec/21/sharingeconomy-divisive-uber-airbnb

Atherton, A. \& Elsmore, P. (2007). Structuring qualitative enquiry in management and organization research. Qualitative Research in Organizations and Management, 2(1): 62-77.

Beer, D. (2013). Popular Culture and New Media: The Politics of Circulation. London: Palgrave Macmillan.

Belk, R. (2014). You are what you can access: Sharing and collaborative consumption online. Journal of Business Research, 67(8): 1595-1600.

Booth, A. (2013, October 13). The Sharing Economy, the Future of Jobs, and 'Postcapitalism'. In Defence of Marxism. Retrieved from: http://www.marxist.com/the-sharing-economy-thefuture-of-jobs-and-postcapitalism-part-three.htm

Botsman, R. (2013). The sharing economy lacks a shared definition. Fast Company. Retrieved from http://www.fast-coexist.com/3022028/the-sharing-economy-lacks-a-shared-definition

Botsman, R., \& Rogers, B. (2010). What's mine is yours: The rise of collaborative consumption. New York: Harper Collins.

Calloway, A. (2016) Apploitation in a city of instaserfs: How the "sharing economy" has turned San Francisco into a dystopia for the working class. The Monitor, January/February:https://www.policyalternatives.ca/publications/monitor/monitorjanuaryfebruar $\mathrm{y}-2016$

CBC News (2015, September 20). Toronto city council votes for new rules to accommodate Uber. CBC News. Retrieved from: http://www.cbc.ca/news/canada/toronto/uber-toronto-citydebate-1.3249983

Community Economies Collective (2001). Imagining and enacting noncapitalist futures. Socialist Review, 28 (3\&4): 93-135 
Chafkin, M. (2015). What makes Uber run? Fast Company. Retrieved from http://www.fastcompany.com/3050250/what-makes-uber-run

Chakraborty, S. (2017). Ola, Uber may find a new rival in HDK Cabs in Karnataka. Live Mint. Retrieved from: http://www.livemint.com/Companies/7jW0mQCYkfzsPlEaYdAsUJ/Ola-Ubermay-find-a-new-rival-in-HDK-Cabs-in-Karnataka.html

Chatterton, P. \& Pickerill, J. (2010). Everyday activism and transitions towards post-capitalist worlds. Transitions of the Institute of British Geographers, 35(4): 475-490.

Chen, L. (2015, September, 28). Uber wants to conquer the world but these companies are fighting back. Forbes. Retrieved from: http://www.forbes.com/sites/liyanchen/2015/09/09/uberwants-to-conquer-the-world-but-these-companies-are-fighting-back-map/\#4a7fc70b2925

Choudary, P. S. (2015). Platform Scale: How an emerging business model helps startups build large empires with minimum investment. Boston: Platform Thinking Labs.

Cohen, B., \& Kietzmann, J. (2014). Ride on! Mobility business models for the sharing economy. Organization \& Environment, 27(3): 279-296.

Cornwall, J. (2011). Worker Co-operatives and Spaces of Possibility: An Investigation of Subject Spaces at Collective Copies. Antipode (00), 1-21 Online First.

Criger, E. (2015, August 21). Majority of Toronto supports Uber: poll. 680 news. Retrieved from: http://www.680news.com/2015/08/21/majority-toronto-supports-uber-poll/

Czarniawska, B., \& Mazza, C. (2003). Consulting as a liminal space. Human Relations, 56(3): 267-288.

Damodaran, A. (2014, June 10). A disruptive cab ride to riches: The Uber payoff. Forbes. Retrieved from http://www.forbes.com/sites/aswathdamodaran/2014/06/10/a-disruptive-cab-rideto-riches-the-uber-payoff/

Davis, J. (2015). Drive at Your Own Risk: Uber's Misrepresentations to UberX Drivers About Insurance Coverage Violate California's Unfair Competition Law. Boston College Law Review, 56, 1097-1142.

Dowling, R., \& McKinnon, K. (2014) 'Identities', for Lee, R., Castree, N., Kitchin, R., Lawson, V., Paasi, A., Radcliffe, S., Withers, C.W.J., (eds) Sage Handbook of Human Geography, Sage Books. 
Fournier, V. (2002) 'Utopianism and the Cultivation of Possibilities: Grassroots movements of hope’ in M. Parker, (Eds.) Utopia and Organisation, Blackwell: Oxford, 189-217.

Friedman, G. (2014) Workers without employers: Shadow corporations and the rise of the gig economy. Review of Keynesian Economics, 2(2): 171-188.

Gioia, D. A., Corley, K. G., \& Hamilton, A. L. (2012). Seeking Qualitative Rigor in Inductive Research: Notes on the Gioia Methodology. Organizational Research Methods, 16(1), 15-31.

Gelber, S. M. (1991). A job you can’t lose: Work and hobbies in the Great Depression. Journal of Social History, 24(4), 741-766.

Gibson-Graham J K (1996) The End of Capitalism (as we knew it), a Feminist Critique of Political Economy. Malden Ma: Blackwell Publishers.

Gibson-Graham J K (2006). A Postcapitalist Politics. Minneapolis, MN: Regents of University of Minnesota.

Gillespie, T. (2010) The politics of ‘platforms’. New Media \& Society, 12 (3): 347-364.

Gold, R. L. (1958). Roles in Sociological Field Observations, Social Forces, 36(3): 217-223.

Healy, S., \& Graham, J. (2008). Building Community Economies: A Postcapitalist Project of Sustainable Development, in D. Ruccio, ed, Economic Representations: Academic and Everyday. Routledge, New York, 291-314.

Isaac, E. (2014). Disruptive Innovation: Risk-Shifting and Precarity in the Age of Uber. Berkley Roundtable on the International Economy BRIE Working Paper 2014-7.

Jeffords, S. (2015, July 30). Insurance industry warns over Uber. Toronto Sun. Retrieved from: http://www.torontosun.com/2015/07/30/insurance-industry-issues-warning-over-uber

Johnston, P. (2015, August 12). T.O. Uber drivers face nearly 200 charges: city official. CP24. Retrieved from http://www.cp24.com/news/t-o-uber-drivers-face-nearly-200-charges-cityofficial-1.2514521

Kashyap, S. and Lulla, A.B. (2017, March 24) Will New Dehli, Karnataka cabbies’ own app be a match for Ola and Uber? Your Story. Retrieved from: https://yourstory.com/2017/03/cabbiesapp-hdk-cabs/ 
Kassan, J., \& Orsi, J. (2012). Legal Landscape of the Sharing Economy, The. J. Envtl. L. \& Litig., 27, 1-20.

Kenney, M. \& Zysman, J. (2016) The rise of the platform economy. Issues in Science and Technology, XXXII (3): http://issues.org/32-3/the-rise-of-the-platform-economy/

Kessler, S. (2015). The sharing economy is dead and we killed it. Fast Company. Retrieved from http://www.fastcompany.com/3050775/the-sharing-economy-is-dead-and-we-killed-it

Kietzmann, J. H., Hermkens, K., McCarthy, I. P., \& Silvestre, B. S. (2011). Social media? Get serious! Understanding the functional building blocks of social media. Business Horizons, 54: 241-251.

Langley, P., \& Leyshon, A. (2017). Platform capitalism: the intermediation and capitalisation of digital economic circulation. Finance and society., 3(1), 11-31.

Lazzarato, M. (2015). Governing by Debt. South Pasadena: Semiotext(e).

Lovink G. \& Tkacz, N. (2015) Moneylab: Sprouting new digital-economic forms. In G. Lovink, N. Tkacz and P. De Vries (eds.) Moneylab Reader: An intervention in digital economy. Amsterdam: Institute of Network Cultures, 13-18.

Martin, C. J., Upham, P., \& Budd, L. (2015). Commercial orientation in grassroots social innovation: Insights from the sharing economy. Ecological Economics, 118: 240-251.

Morozov, E., (2013). The 'sharing economy' undermines workers' rights [Online]. Retrieved from: https://evgenymorozov.tumblr.com/post/64038831400/the-sharing-economyunderminesworkers-rights (Accessed November 11, 2015).

Morozov, E. (2015) Where Uber and Amazon rule: Welcome to the world of the platform. The Observer, June 7th: Retrieved from:

http://www.theguardian.com/technology/2015/jun/07/facebook-uber-amazonplatform-economy

O’Dwyer, R. (2015) Money talks: The enclosure of mobile payments. In G. Lovink et al, Eds, MoneyLab Reader: an intervention in digital economy. Amsterdam: Institute of Network Cultures, 230-244. 
Orsi, J. (2013, September 13). The Sharing Economy Just Got Real. Shareable. Retrieved from: http://www.shareable.net/blog/the-sharing-economy-just-got-real

Owram, K. (2015, September, 8). Uber’s Canadian launch of ride-sharing service greeted with controversy. Financial Post. Retrieved from: http://business.financialpost.com/entrepreneur/fpstartups/uber-technologies-inc-toronto-launch? lsa=99e2-a15d

Parker, G. G., van Alstyne, M. W. and Choudary, P.S. (2016). Platform revolution: How networked markets are transforming the economy--and how to make them work for you. New York: W. W. Norton.

Parker, M., Cheney, G., Fournier, V., and Land, C. (2014) The Routledge Companion to Alternative Organization. London: Routledge.

Reich, R. (2015). Share the scraps economy. Retrieved from http://robertreich.org/post/109894095095

Rogers, B. (2015). Social Costs of Uber, The. U. Chi. L. Rev. Dialogue, 82, (85): 85-102.

Ross, A. (2013). In search for the lost paycheck. In T. Scholtz (Ed.), Digital Labour - The Internet as Playground and Factory. Routledge: New York.

RT news (2015, December, 9). 'Uber is illegal': Toronto taxi protesters. RT News. Retrieved from: https://www.rt.com/news/325221-uber-taxi-protest-toronto/

Toronto Star. (2016, July 8). Ontario approves insurance plan aimed at Uber. Toronto Star. Retrieved from: https://www.thestar.com/news/gta/2016/07/07/ontario-approves-insurance-planaimed-at-uber.html

van Dijck, J. (2013). The culture of connectivity: A critical history of social media. Oxford: Oxford University Press.

Wilson, A. D. (2013) 'Beyond alternative: exploring the potential for autonomous food spaces', Antipode, 45(3): 719-737.

Wright, C., Nyberg, D. De Cock, C., \& Whiteman, G. (2013). Future Imaginings: Organizing in Response to Climate Change, Organization, 20(5): 647-658

Zickar, M. J., \& Carter, N. T. (2010). Reconnecting with the spirit of workplace ethnography. A historical review. Organizational Research Methods, 13(2): 304-319. 
Postcapitalist precarious work and those in the 'drivers"' seat 

${ }^{1}$ All names have been changed to pseudonyms 



\section{Legend:}

(.............. Part-time drivers

-4... Full-time (non-professional) drivers

Full-time (professional) drivers

* $\quad$ Some professional drivers also expressed a sense of control and flexibility 